Western University

Scholarship@Western

FIMS Working Papers

Information \& Media Studies (FIMS) Faculty

2013

\title{
Comparison of Fair Dealing and Fair Use in Education Post-Pentalogy
}

Lisa Di Valentino

Faculty of Information and Media Studies, University of Western Ontario, ldivalen@uwo.ca

Follow this and additional works at: https://ir.lib.uwo.ca/fimswp

\section{Citation of this paper:}

Di Valentino, Lisa, "Comparison of Fair Dealing and Fair Use in Education Post-Pentalogy" (2013). FIMS Working Papers. 3. https://ir.lib.uwo.ca/fimswp/3 


\section{Comparison of Fair Dealing and Fair Use in Education Post-Pentalogy}

Lisa Di Valentino, September 3, 2013*

While traditionally American fair use has been thought of as broader in scope than Canadian fair dealing, I claim that in 2013 this is no longer the case. I further argue that educational administrators and academic and library associations in Canada have yet to take full advantage of this expansion of users' rights.

Two events in 2012 significantly altered the Canadian copyright landscape, particularly with regards to educational fair dealing. The Supreme Court handed down five important decisions in copyright law, known as the "Copyright Pentalogy"; two of these decisions, Alberta (Education) v. Canadian Copyright Licensing Agency (Access Copyright) (Alberta) and Society of Composers, Authors and Music Publishers of Canada v. Bell Canada (SOCAN) dealt specifically with fair dealing. ${ }^{1}$ These cases provided guidance in interpreting the six fair dealing factors set out in CCH Canadian Ltd. v. Law Society of Upper Canada ${ }^{2}(\mathrm{CCH})$ and confirmed that fair dealing is a user's right and must not be interpreted restrictively.

The second major event was the enactment of Bill C-11, which amended the Canadian Copyright Act to include "education, parody and satire" as allowable fair dealing purposes. ${ }^{3}$

In contrast with the more open-ended and flexible American doctrine of fair use, fair dealing is traditionally thought to be rigid due its circumscribed list of permissible purposes. A given

\footnotetext{
* Copyright Lisa Di Valentino, 2013. This work is licensed under a Creative Commons Attribution 2.5 Canada Licence (CC-BY).

${ }^{1}$ Alberta, 2012 SCC 37, [2012] 2 SCR 345, online: CanLII <http://canlii.ca/t/fs0v5 >; SOCAN, 2012 SCC 36, [2012] 2 SCR 326, online: CanLII <http://canlii.ca/t/fs0vf $>$.

2004 SCC 13, [2004] 1 SCR, online: CanLII 〈http://canlii.ca/t/1glp0〉.

${ }^{3}$ An Act to amend the Copyright Act, 1st Sess., 41st Parl., 2011 (assented to 29 June 2012), S.C. 2012, c. 20, online: Parliament of Canada <http://www.parl.gc.ca/HousePublications/Publication.aspx?DocId=5144516\&File=4>.
} 
dealing must first fall into one of the enumerated purposes (first stage) before the six factor test can be considered (second stage). Prior to 2012, the purposes were limited to research, private study, criticism, review, and news reporting. It was unclear whether common educational practices such as multiple copies for classroom use (which is an explicitly permitted purpose under American fair use) would pass the first stage of the fair dealing analysis. Educational administrators, then, were cautious in allowing this type of copying to take place in colleges and universities without the safety net of a blanket agreement with copyright owners. ${ }^{4}$

The effect of the Copyright Pentalogy and legislative amendments has essentially been to broaden the scope of fair dealing. In this paper I argue that in fact fair dealing is now broader in scope than fair use, at least with respect to the education and library sectors, in that a potential defendant has a lesser burden to overcome in a fair dealing analysis.

In Part I I give a brief and general overview of copyright in Canada and the United States. In Part II I compare the legislation and jurisprudence specifically with respect to fair dealing and fair use, using the fairness factors as a guide. Specifically, this part will examine differences with respect to the fairness factors in general, transformativity, amount and substantiality, market harm and licences, and institutional practice and policy. Part III is a discussion of the advocacy efforts of Canadian and American educational and library professional associations and the development of best practices and guidelines. I conclude that colleges and universities in Canada may now confidently develop copyright policies that reflect the rights of users, but educational administrators and associations in Canada are lagging behind their American counterparts in leveraging this opportunity.

\footnotetext{
${ }^{4}$ Samuel Trosow, "Bill C-32 and the Educational Sector: Overcoming Impediments to Fair Dealing" in Michael Geist, ed., From "Radical Extremism” to "Balanced Copyright”: Canadian Copyright and the Digital Agenda (Toronto: Irwin Law, 2010) 541 at 546, online: Irwin Law <http://www.irwinlaw.com/pages/content-commons/billc-32-and-the-educational-sector--overcoming-impediments-to-fair-dealing---samuel-e-trosow $>$.
} 


\section{PART I - The law of fair dealing and fair use}

The purpose of copyright is explicitly addressed in the Constitution of the United States:

Congress is empowered "To promote the Progress of Science and useful Arts, by securing for limited Times to Authors and Inventors the exclusive Right to their respective Writings and Discoveries." ${ }^{5}$

In the Canadian Constitution Act, 1867, the federal Parliament is authorized to make laws related to copyright, but there is no specific indication of the objective of these laws. ${ }^{6}$ The Copyright Act itself does not include any discussion of its purpose. ${ }^{7}$ The preamble of Bill C-11, however, describes the Copyright Act as "an important marketplace framework law and cultural policy instrument" that "supports creativity and innovation". 8

Daniel Gervais argued in 2005 that the Canadian copyright laws have a "dual economic purpose" of rewarding copyright owners while not impeding dissemination and access. ${ }^{9}$ This dual purpose is fulfilled by a careful balancing of the interests of copyright owners and users. The Supreme Court in Théberge v. Galerie d'Art du Petit Champlain inc. (Théberge) stated that "The proper balance among these and other public policy objectives lies not only in recognizing the creator's rights but in giving due weight to their limited nature. ${ }^{, 10}$ In this case, the Court was not engaging in a fair dealing analysis, but rather addressing the proprietary rights of those who had purchased a copy of the work. Nonetheless, the Court asserted that copyright owners' rights were not to be given an overly-expansive reading lest the balance be tilted too far in one direction. This

\footnotetext{
${ }^{5}$ art. I, § 1, cl. 8, online: WikiSource

〈https://en.wikisource.org/wiki/Constitution_of_the_United_States_of_America〉.

${ }^{6}$ (UK), 30 \& 31 Vict., c. 3, reprinted in R.S.C. 1985, App. II, No. 5, s. 91, online: Government of Canada $<$ http://laws-lois.justice.gc.ca/eng/Const/page-1.html $>$.

${ }^{7}$ RSC 1985, c C-42, online: CanLII <http://canlii.ca/t/7vdz $>$.

${ }^{8}$ supra note 3.

${ }^{9}$ Daniel Gervais, "The Purpose of Copyright Law in Canada" (2005) 2:2 UOLTJ Journal 315 at 356, online: UOLTJ <http://www.uoltj.ca/articles/vol2.2/2005.2.2.uoltj.Gervais.315-356.pdf $>$.

${ }^{10} 2002$ SCC 34, [2002] 2 SCR at para. 31, online: CanLII <http://canlii.ca/t/51tn $>$.
} 
characterization has been said to be similar to the American policy foundation of encouraging innovation. $^{11}$

Then in $\mathrm{CCH}$ the Court took the analysis a step further: not only does the user (and by extension, the public) have an interest to be considered in copyright law, she has a right to deal with a copyrighted work in certain ways, and not only because she may own a physical copy of the work. ${ }^{12}$ This right - represented by fair dealing and other exceptions - is an "integral part" of the Copyright Act. ${ }^{13}$ As such, limitations on owners' exclusive rights "must not be interpreted restrictively." ${ }^{\prime 14}$ Alberta and SOCAN provided further support to this characterization, declaring that the purpose of the dealing must be looked at from the perspective of the end user who is taking advantage of her right. ${ }^{15}$

American copyright has also been characterized as having a balancing effect. The House of Representatives report addressing the proposed fair use provision in 1976 stated that "it is the intent of this legislation to provide an appropriate balancing of the rights of creators, and the needs of users." ${ }^{\prime 16}$ However, the balancing itself is instrumental to the goal of the public good, and a maximalist approach - in which protection of owners' rights is strengthened - may well serve this ultimate goal in certain circumstances. Teresa Scassa points out: "For example, if society would benefit economically from a strongly competitive digital economy, then the interests of society might be best served by a very robust copyright system that strongly favours

\footnotetext{
${ }^{11}$ Robert G. Howell, "Recent Copyright Developments: Harmonization Opportunities for Canada" (2004) 1 UOLTJ 149 at 169, online: UOLTJ <http://www.uoltj.ca/articles/vol1.1-2/2003-2004.1.1-2.uoltj.Howell.149-171.pdf>.

12 supra note 2.

13 ibid. at para. 48.

14 ibid.

${ }^{15}$ Alberta, supra note 1 at para. 22; SOCAN, supra note 1 at para. 34.

${ }^{16}$ U.S., House Judiciary Committee, Copyright Law Revision (H.R. No. 94-1476) (Washington, D.C.: U.S. Government Printing Office), online: Wikisource <http://en.wikisource.org/wiki/Copyright_Law_Revision_(House_Report_No.994-1476)>.
} 
the rights of owners of copyright." ${ }^{17}$ In Canadian copyright law, on the other hand, the rights of the user are integral to the copyright scheme; the balance is not between owners' rights on the one hand and users' needs on the other, but between two sets of rights. Benefit to the public can only come from acknowledging that the use of copyrighted works is equally as important as their protection, ${ }^{18}$ since authors are also consumers of works, and users can also be creators, and these dual roles reflect the "intertextuality of creation". ${ }^{19}$ This is especially true for purposes such as parody and satire, where the original work is directly incorporated into the new one, and for research and education, where "creators" and "users" are engaged in a continuous exchange of knowledge. $^{20}$

The representation of fair dealing and other exceptions as users' rights by the Supreme Court is not mere rhetoric. Evidence of its effect can be found elsewhere in Canadian copyright law and jurisprudence, which I will discuss in detail in Part II, demonstrating that Canadian fair dealing post-Pentalogy is in many ways broader in scope than American fair dealing.

\section{PART II - Comparison of fair dealing and fair use}

\section{$\underline{\text { II. } 1 \text { - Fairness purposes }}$}

Traditionally, fair use was considered to be more expansive in scope than fair dealing, primarily because the U.S. Copyright Act does not limit the purposes to which a fair use can be put ("purposes such as"), while the Canadian Copyright Act provides a closed list of fair dealing

\footnotetext{
${ }^{17}$ Teresa Scassa, "Recalibrating Copyright Law?: A Comment on the Supreme Court of Canada's Decision in CCH Canadian Limited et al. v. Law Society of Upper Canada" (2004) 3:2 Canadian Journal of Law and Technology 89 at 97, online: CJLT <http://cjlt.dal.ca/vol3_no2/index.html>.

18 SOCAN, supra note 1 at para. 11.

19 Abraham Drassinower, "Taking User Rights Seriously" in Michael Geist, ed., In the Public Interest: The Future of Canadian Copyright Law (Toronto: Irwin Law, 2005) 462, online: Irwin Law $\langle$ http://www.irwinlaw.com/pages/in-the-public-interest--the-future-of-canadian-copyright-law>.

${ }^{20}$ Meera Nair, "Fairness of Use: Different Journeys" in Michael Geist, ed., The Copyright Pentalogy: How the Supreme Court of Canada Shook the Foundations of Copyright Law (Ottawa: University of Ottawa Press, 2013) 235, online: University of Ottawa Press <http://www.press.uottawa.ca/the-copyright-pentalogy $>$.
} 
purposes. Prior to $\mathrm{CCH}$ in 2004 , therefore, the purposes were generally interpreted restrictively. ${ }^{21}$ For example, in Compagnie Générale des Établissements Michelin-Michelin \& Cie v. National Automobile, Aerospace, Transportation and General Workers Union of Canada (CAW-Canada) (Michelin), a 1996 decision, the Federal Court decided that the Union's use of the "Michelin Man" character on protest pamphlets was not fair dealing, because parody was not an enumerated purpose and could not be considered a form of criticism, as purposes are to be read literally and restrictively. ${ }^{22}$

The ratio of $\mathrm{CCH}$, on the other hand, established the principle that the purposes in the first part of the fair dealing test (whether the dealing is for an enumerated purpose) were to be given a "large and liberal interpretation" in keeping with the notion of users' rights. ${ }^{23}$ Some commentators have noted the apparent convergence of the scope of fair use and fair dealing purposes subsequent to the $\mathrm{CCH}$ decision, ${ }^{24}$ although there had been worry that the enumerated purposes were still not broad enough to encompass emerging practices based on new technology. ${ }^{25}$

The Court in Alberta reiterated the idea of a large and liberal interpretation when it concluded that the research or private study purpose was broad enough to encompass copies of excerpts made for students on the initiative of the teacher, because it is the student who is the end user, and thus it is the student's purpose that is under consideration: "The teacher/copier therefore shares a symbiotic purpose with the student/user who is engaging in research or private study.",26

\footnotetext{
${ }^{21}$ Giuseppina D'Agostino notes that there were some liberal interpretations as well ("Healing Fair Dealing? A Comparative Copyright Analysis of Canada's Fair Dealing to U.K. Fair Dealing and U.S. Fair Use" (2008) 53 McGill L. J. 309 at 330-331, online: SSRN <http://ssrn.com/abstract=1014404>.)

${ }^{22}$ [1997] 2 FC 306 at para. 70, online: CanLII <http://canlii.ca/t/4g4v $>$.

23 supra, note 2 at para. 51.

${ }^{24}$ D’Agostino, supra note 21; Daniel Gervais, "Canadian Copyright Law Post-CCH” (2004) 18 I. P. J. 131.

${ }^{25}$ Carys Craig, "The Changing Face of Fair Dealing in Canadian Copyright Law" in Michael Geist, ed., In the Public Interest: The Future of Canadian Copyright Law (Toronto: Irwin Law, 2005) 437, online: Irwin Law <http://www.irwinlaw.com/pages/in-the-public-interest--the-future-of-canadian-copyright-law>.

${ }^{26}$ supra note 1 at para. 23.
} 
Likewise, in SOCAN, the Court said, "In mandating a generous interpretation of the fair dealing purposes, including 'research', the Court in $\mathrm{CCH}$ created a relatively low threshold for the first step so that the analytical heavy-hitting is done in determining whether the dealing was fair." 27

In response to the federal government's public copyright consultation process in 2009 , a number of submitters recommended that the fair dealing provision be made more flexible by the addition of "such as" to the list of fair dealing purposes, much like American fair use. ${ }^{28}$ While Parliament did not make this particular change, it did add "education, parody or satire" to the list of enumerated purposes.

After the Copyright Pentalogy decisions were issued, and the statutory amendments in force, Michael Geist wrote that "The Court's fair dealing analysis, when coupled with Bill C-11's statutory reforms, may have effectively turned the Canadian fair dealing clause into a fair use provision." 29 A dealing for the purpose of education will inevitably pass the first part of the fair dealing test, just as it would be considered an acceptable purpose in fair use. Of course, the dealing must still be adjudged to be "fair" as per the several factors, and it is this subject that is addressed in the following sections.

\footnotetext{
27 supra note 1 at para. 27.

${ }^{28}$ Canadian Alliance of Student Associations, "The Student Vision for Amending the Copyright Act" (2009), online: Industry Canada <http://www.ic.gc.ca/eic/site/008.nsf/eng/00911.html >; Canadian Association of University Teachers, "Submission by the Canadian Association of University Teacher (CAUT) to The Copyright Consultation" (2009), online: Industry Canada <http://www.ic.gc.ca/eic/site/008.nsf/eng/02175.html>; Jeremy de Beer, "Response to the Government of Canada's Copyright Consultation" (2009), online: Industry Canada <http://www.ic.gc.ca/site/008.nsf/eng/02737.html>; Michael Geist, "Copyright Consultations Submission" (2009) online: Industry Canada <http://www.ic.gc.ca/eic/site/008.nsf/eng/02204.html>; Howard Knopf, "Copyright Consultation Submission” (2009), online: Industry Canada <http://www.ic.gc.ca/site/008.nsf/eng/01899.html>; Samuel Trosow "Copyright Consultation Submission" (2009), online: Industry Canada $<$ http://www.ic.gc.ca/eic/site/008.nsf/eng/02714.html >.

${ }^{29}$ Michael Geist, "Fairness Found: How Canada Quietly Shifted from Fair Dealing to Fair Use" in Michael Geist, ed., The Copyright Pentalogy: How the Supreme Court of Canada Shook the Foundations of Copyright Law (Ottawa: University of Ottawa Press, 2013) 157 at 159, online: University of Ottawa Press <http://www.press.uottawa.ca/the-copyright-pentalogy >.
} 


\section{$\underline{\text { II. } 2 \text { - Fairness factors }}$}

Unlike the four American fair use factors, which were codified in the Copyright Act in 1976, Canada's six fair dealing factors are still common law. They were first set out by Linden J.A. in the $C C H$ Federal Court of Appeal decision, ${ }^{30}$ and given support and further elucidation by the Supreme Court. ${ }^{31}$

Despite that the two sets of factors differ in number, they can be mapped on to each other fairly easily:

\begin{tabular}{|c|c|}
\hline Fair dealing 32 & Fair use $^{33}$ \\
\hline 1. The purpose of the dealing. & \multirow{2}{*}{$\begin{array}{l}\text { 1. The purpose and character of the use, } \\
\text { including whether such use is of a commercial } \\
\text { nature or is for non-profit educational } \\
\text { purposes. }\end{array}$} \\
\hline 2. The character of the dealing. & \\
\hline 3. The amount of the dealing. & $\begin{array}{l}\text { 3. The amount and substantiality of the portion } \\
\text { used in relation to the copyrighted work as a } \\
\text { whole. }\end{array}$ \\
\hline 4. Alternatives to the dealing. & $\begin{array}{l}\text { No fair use equivalent, but parts of factor } 4 \\
\text { have some relevance as to alternatives } \\
\text { (specifically, the availability of a licence). }\end{array}$ \\
\hline 5. The nature of the work. & 2. The nature of the copyrighted work. \\
\hline 6. Effect of the dealing on the work. & $\begin{array}{l}\text { 4. The effect of the use upon the potential } \\
\text { market for or value of the copyrighted work. }\end{array}$ \\
\hline
\end{tabular}

\footnotetext{
${ }^{30} 2002$ FCA 187, [2002] 4 FC 213 at paras. 150-160, online: CanLII 〈http://canlii.ca/t/4j5c〉 [hereafter $C C H$ 2002].

${ }^{31} \mathrm{CCH}$, supra note 2 at paras. 53-60.

${ }^{32}$ ibid. at paras. $54-59$.

${ }^{33}$ Copyright Act, 17 U.S.C. $\left.\S \S 107(1)\right)-107(4)$.
} 
All four fair use factors must be taken into consideration, according to the text of $\S 107$ ("In determining whether the use made of a work in any particular case is a fair use the factors to be considered shall include..." [emphasis added]), but other, non-enumerated factors may be looked at in addition. By contrast, the Federal Court of Appeal in $\mathrm{CCH}$ stated that the six named fair dealing factors "are usually among the non-exhaustive list of considerations." 34 Likewise, the Supreme Court in $\mathrm{CCH}$ stated that not all of the factors will need to be considered in every case, and that they are more of an "analytical framework" than a strict requirement. ${ }^{35}$

There has been criticism of the Canadian approach. David Vaver has said that leaving the consideration of factors up to the courts makes the concept of fair dealing "inherently amorphous", ${ }^{36}$ implying that if the factors were enumerated in the statute the process would be clearer. However, the same amorphousness plagues fair use as well: In Cambridge University Press v. Becker (2012) (Georgia State) the District Court called the statutory factors a "very fluid framework for resolving fair use issues", 37 and that the process is a "value-laden review" 38 that is undertaken "in light of the purposes of copyright.". 39 Similarly, Kenneth Crews has argued that rigid fair use guidelines for use in schools are contrary to the intent of Congress in enacting the fair use provision. ${ }^{40}$

On the other hand, Giuseppina D’Agostino asserted in 2008 that the Canadian approach is more flexible and ultimately pro-user than the American approach, in that certain factors such as

\footnotetext{
${ }^{34}$ CCH 2002, supra note 30 at para. 150 [emphasis added].

35 supra note 2 at para. 53.

${ }^{36}$ David Vaver, Intellectual Property Law (Toronto: Irwin Law, 2011) at 236.

${ }^{37} 863$ F.Supp.2d 1190 (N.D.Ga. 2012) at 1210, online: Justia < http://docs.justia.com/cases/federal/districtcourts/georgia/gandce/1:2008cv01425/150651/1/>.

38 ibid.

39 ibid.

${ }^{40}$ Kenneth D. Crews, "The Law of Fair Use and the Illusion of Fair Use Guidelines" (2001) 62:2 Ohio State Law

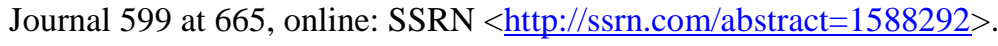


market effect tend to weight against a defendant in a fair use analysis, but are not mandatory to consider in a fair dealing analysis. ${ }^{41}$

Whether or not the particular structural approach to the fairness factors differs significantly between the two jurisdictions, the judicial interpretation of the factors can be shown to reflect a more pro-user tendency in Canadian fair dealing than in American fair use.

\section{$\underline{\text { II.3 - Transformativity }}$}

Transformativity - the extent to which the use or dealing alters the nature of the original work or its utility - is an element of the first fair use factor (the purpose and character of the use). It is also sometimes known as a "productive use", in that it produces something beyond or in addition to the original work itself, rather than simply being a straight copy. It has been said that transformativity is the most important element of the first factor, ${ }^{42}$ or indeed of the entire fair use analysis. $^{43}$

At the very least, where a use is deemed to be more transformative or productive, the remaining factors become less important. ${ }^{44}$ Even where the use is non-transformative, this fact renders the other factors (except for market effect) ${ }^{45}$ less significant, ${ }^{46}$ or requires that they be interpreted more restrictively (as in Georgia State, where a non-transformative use means that the copied

\footnotetext{
${ }^{41}$ supra note 21 at 346 . Since the Copyright Pentalogy, she has changed her opinion somewhat, arguing that the more "arithmetical" and "absolutist" approach to considering the six factors in Alberta and SOCAN is not consistent with the "large and liberal" approach championed by $\mathrm{CCH}$ ("The Arithmetic of Fair Dealing at the Supreme Court of Canada" in Michael Geist, ed., The Copyright Pentalogy: How the Supreme Court of Canada Shook the Foundations of Copyright Law (Ottawa: University of Ottawa Press, 2013) 187 at 190, online: University of Ottawa Press <http://www.press.uottawa.ca/the-copyright-pentalogy>).

${ }^{42}$ Pierre N. Leval, "Toward A Fair Use Standard" (1990) 103 Harvard Law Review 1105 at 111.

${ }^{43}$ Patricia Aufderheide \& Peter Jaszi, Reclaiming Fair Use (Chicago: The University of Chicago Press, 2011) at $82 \mathrm{ff}$.

${ }^{44}$ Melville B. Nimmer \& David Nimmer, Nimmer on Copyright (New York: Matthew Bender \& Co., Inc., 1998) § $13.05[\mathrm{~A}][1][\mathrm{b}]$.

${ }^{45}$ Market effect will be discussed in more detail in section II.5, infra.

${ }^{46}$ Princeton University Press v. Michigan Document Services, 99 F.3d 1381 (6th Cir. 1996) at para. 32, online: Cornell LII <http://www.law.cornell.edu/copyright/cases/99_F3d_1381.htm> .
} 
excerpts would have to be "decidedly small" in order to be fair ${ }^{47}$ ). In American Geophysical Union v. Texaco Inc. (Texaco), the Second Circuit related the notion of transformativity to the "value" of the copy, or more accurately, the value of the user's contribution to the advancement of arts and sciences in making the copy. The creation of an untransformed copy does not make any such contribution - according to the Court - and so is less likely to be considered fair use. ${ }^{48}$

A notable exception is Sony Corporation of America v. Universal City Studios, Inc. (Sony), where the Supreme Court cautioned against trying to draw a bright line between "productive" and "non-productive" uses, and rather placed the focus on the economic effect of the copying (the fourth factor). ${ }^{49}$

The level of importance of transformativity in Canada is arguably lower than it is in the United States, if one considers that it is rarely brought up in fair dealing cases. In Century 21 Canada Ltd. Partnership v. Rogers Communications Inc. (2011), the British Columbia Supreme Court called transformativity an "American concept" $"$ and said that "Canadian courts have not recognized 'transformative use' as a characteristic of fair dealing." ${ }^{\text {51 }}$ In SOCAN the Supreme Court likewise did not accept the plaintiff's reliance on the American view of transformativity in its argument that the offering of song previews was unfair. ${ }^{52}$

Some transformative uses in Canada may also fall under the specific non-commercial usergenerated content exception added to the Copyright Act in 2012, which allows for the

\footnotetext{
47 supra note 37 at 1232.

${ }^{48} 60$ F.3d 913 (2nd Cir 1994) at 923, online: Cornell LII of scientific research." (at 933)

${ }^{49} 464$ U.S. 417, 104 S.Ct. 774 (1984) at 455 fn 40, online: Cornell LII <http://www.law.cornell.edu/copyright/cases/464_US_417.htm>.

502011 BCSC 1196 at para. 54, online: CanLII <http://canlii.ca/t/fn00h>.

51 ibid. at para. 234.

52 supra note 1 at para. 23.
}

<http://www.law.cornell.edu/copyright/cases/60_F3d_913.htm>. In his dissent, Justice Jacobs argues that copying articles for use in the course of research does generate additional value in that it is part of a "transformative process 
incorporation of an existing work in the creation of a new one, subject to certain requirements. ${ }^{53}$

While fair dealing is always available,${ }^{54}$ it can be argued that the existence of a separate exception for "more transformative" works is an indication that "less transformative" works would be more likely in Canada than in the U.S. to be considered fair, at least in non-commercial contexts such as education and library services.

This reduced emphasis on transformativity may also be a reflection of the conceptualization of fair dealing as a user's right rather than a narrowly-construed justification, in that the user is not necessarily required to "do" anything to the work (or as the court in Texaco might put it, "generate value") in order to be entitled to deal with it. This is especially relevant for educational uses, which are, in most cases, "straight copying" of excerpts (for class handouts, supplemental readings, or course packs) rather than directly transformative.

\section{$\underline{\text { II.4 - Amount and substantiality }}$}

As noted above, in fair use, the level of transformativity (being the character of the use) and the amount of the work used can be placed in relation to one another. In Georgia State, the low level of transformativity means that the amount used must be correspondingly low. The particular uses that happened to adhere to the Court's ad-hoc specifications were adjudged to be fair. By contrast, in Authors Guild, Inc. v. HathiTrust (HathiTrust), entire works were copied, but the character of the use was highly transformative, and the use was deemed to be fair. ${ }^{55}$ In Texaco, journal articles were considered to be separate works with individual copyrights, which weighed against fairness. (Again, in Sony, entire works in the form of television programmes were copied, but the Court lent more significance to the lack of economic harm to the copyright owners.)

\footnotetext{
${ }^{53}$ supra, note 7, s. 29.21.

${ }^{54} \mathrm{CCH}$, supra note 2 at para. 49.

55902 F.Supp.2d 445 (S.D.N.Y. 2012), online: Google Scholar

<http://scholar.google.com/scholar_case?case=12309942784662899319 >.
} 
In Canada, although there is no apparent significance to the transformativity factor, there is a relationship between the amount of the dealing and the purpose of the dealing. For example, where the purpose is research or private study (or, presumably, education), it may be fair to copy an entire academic article, whereas a dealing for the purpose of criticism or review would be more likely to be fair if only a small part of the work is duplicated. ${ }^{56}$

However, there is little guidance as to what proportion of a work is fair under what purpose. In $\mathrm{CCH}$, the copying at issue was for research purposes and was generally of law review articles, parts of monographs, and annotated cases and legislation. However, because the Great Library's copying policy ${ }^{57}$ was considered fair, the Court determined that there was no need to examine each individual instance of copying via the six factors. ${ }^{58}$

In SOCAN, the Supreme Court agreed with the Copyright Board's characterization of a 30second preview as a "modest dealing" when compared with a four minute song.

Neither the Supreme Court decision in Alberta, the Federal Court of Appeal Decision, nor the Copyright Board's tariff reasons stated the actual proportions of the textbooks that were copied (i.e. the length of the excerpts); this is because the issue primarily turned on whether the copies were for an allowable purpose (the first step of the fair dealing test). The Copyright Board merely noted that the teachers copied "relatively short excerpts" from the works. 59

Access Copyright's recent copyright infringement suit against York University, if it goes to the courts, may provide guidance for educational institutions. Access Copyright claims that York's

\footnotetext{
${ }^{56} \mathrm{CCH}$, supra note 2 at para. 56.

${ }^{57}$ The Great Library's policy indicated that requests for more than five percent of a secondary source, or more than two articles from a volume, may be refused at the discretion of a reference librarian.

${ }^{58}$ The role of internal policy is discussed further at Section II.6, infra.

${ }^{59}$ Re: Statement of Royalties to be Collected by Access Copyright for the Reprographic Reproduction, in Canada, of Works in its Repertoire: Educational Institutions 2005-2009 (26 June 2009) at para. 104, online: Copyright Board 〈http://www.cb-cda.gc.ca/decisions/2009/Access-Copyright-2005-2009-Schools.pdf>.
} 
fair dealing policy leads to copying outside the scope of fair dealing. ${ }^{60}$ If the court decides that York's policy is fair, it could provide a safe harbour of sorts for certain educational use of excerpts.

Besides the transformativity consideration, both fair dealing and fair use appear to be in agreement on the notion that fairness is more likely when the quantity or proportion of the work copied is no more than is necessary for the particular purpose. However, there is a variance in interpretations of the significance of an excerpt's quality or importance to the work.

Canadian courts have so far not considered qualitative issues directly in fair dealing analysis. In several cases, including Michelin and Théberge, the courts indicated that a copyright owner's exclusive rights (as listed in s. 3(1) of the Copyright Act) include the right to copy a "substantial part" of the work, and that substantiality must be considered in terms of both quantity and quality. ${ }^{61}$ However, these discussions relate to whether or not the copyright owner's rights have been engaged at all (i.e. whether a need for further analysis is triggered), and not to the amount taken in the context of a fair dealing analysis.

In $\mathrm{CCH}$, it was acknowledged that both quantity and quality of the dealing in relation to the whole work are considerations in fair dealing, but a quality analysis was not applied to the particular copying in question. In SOCAN, the Supreme Court pointed out that the sound quality

\footnotetext{
${ }^{60}$ The Canadian Copyright Agency ("Access Copyright") v. York University (8 April 2013) Federal Court File No. T-578-13 (Statement of Claim at paras. 22-25), online: Scribd <http://www.scribd.com/doc/134926954/AC-v-YorkStatment-of-Claim-T-578-13-Doc1>. In the policy, "short excerpt" is defined as "10\% or less of a work, or no more than (a) one chapter from a book; (b) a single article from a periodical;..." (York University, "Fair Dealing Guidelines for York Faculty and Staff" (11 November 2012), online: York University <http://copyright.info.yorku.ca/fair-dealing-requirements-for-york-faculty-and-staff/> [emphasis original]). Schedule "B" of Access Copyright's complaint lists the works that are at issue but does not indicate how much of each was copied (online: Scribd < http://www.scribd.com/doc/135119290/Access-Copyright-v-YorkU-ScheduleB>).

${ }^{61}$ Michelin, supra note 22 at para. 54; Théberge, supra note 10 at para. 142.
} 
of the previews were lower than that of the purchased songs, but did not address whether or not the previews represented the "heart" of the songs.

By contrast, several U.S. fair use cases have addressed the quality of the portion copied, and in some cases have found that a use was not fair in part because of this consideration. In the 1985 decision Harper \& Row Publishers, Inc. v. Nation Enterprises (Harper \& Row), the Supreme Court said the qualitative value of the copied extracts could be presumed because a substantial portion of the infringing work was taken verbatim. ${ }^{62}$ The District Court took a similar view in the 1991 case Basic Books, Inc. v. Kinko's Graphics Co. (Basic Books), concluding that the fact that the professors used them was evidence that they were critical parts of the work. ${ }^{63}$ The Sixth Circuit in Princeton University Press v. Michigan Document Services (Princeton) reiterated this idea. $^{64}$

More recently, while only five out of 48 uses at issue in Georgia State were found to be unfair, in one of those findings the third factor (amount of the use) weighed heavily in the plaintiff's favour - not only because the total extract was not "decidedly small", but also because it represented "the heart of the work." 65

The reasoning above in Harper \& Row, Basic Books, and Princeton is particularly worrisome from a user's perspective. If the reproduction of an extract of a work leads to the presumption that the copied part is critical to the work (because the copier chose to reproduce it) and thus

\footnotetext{
62471 U.S. 539, 105 S.Ct. 2218 (1985) at 565, online: Google Scholar $\langle$ http://scholar.google.com/scholar_case?case $=12801604581154452950$ > $>$.

${ }^{63} 758$ F. Supp. 1522 (S.D. N.Y. 1991) at 1533, online: Boston College <http://www.bc.edu/bc_org/avp/cas/comm/free_speech/basicbooks.html>. ${ }_{65}^{64}$ supra, note 46 at para. 40.

${ }^{65}$ supra, note 37 at 1359.
} 
weighs against the defendant in fairness factor three, then essentially any reproduction is unfair to some degree from the outset. ${ }^{66}$

There is no such presumption in Canadian fair dealing law; given the Supreme Court's description of fair dealing as a user's right, it would be difficult to imagine a court accepting the absurd claim that the very exercise of this right means that it is less likely to apply.

\section{$\underline{\text { II.5 - Market harm and licences }}$}

In Harper \& Row, the court stated that the market effect factor is the single most important element of fair use. ${ }^{67}$ This notion was repeated in Basic Books, and in Princeton the court characterized it as "first among equals." "68 Note, however, that in these three cases the copying was done on a commercial basis. In Georgia State, where the copying was done in the context of non-profit education, the Court seemed to reject the idea that market effect is most important: "It is hornbook law that there is no across the board rule for what weight should be given to each factor or how the factors should be applied."69 The HathiTrust decision did not address the relative importance of the fourth factor.

The U.S. fair use analysis includes a "market harm test", where, for a non-commercial use, the copyright owner need only show that if there use were widespread, it would substantially and adversely affect the market or potential market. ${ }^{70}$ This test was considered in Harper \& Row, Sony, Campbell v. Acuff-Rose Music, Inc., Basic Books, Texaco, Princeton (in which the Court

\footnotetext{
${ }^{66}$ In Nimmer on Copyright, the circularity of this reasoning is pointed out (supra note 44, § 13.05[A][3]).

${ }^{67}$ supra, note 62 at 567.

${ }^{68}$ Basic Books, supra note 63 at 1534; Princeton, supra note 46 at para. 17.

${ }^{69}$ supra note 37 at 1210.

${ }^{70}$ Nimmer on Copyright, supra note 44, § 13.05[A][4]. A similar test was discussed in Folsom v. Marsh, an 1841 appeal decision: "But if the defendants may take three hundred and nineteen letters, included in the plaintiffs' copyright, and exclusively belonging to them, there is no reason why another bookseller may not take [another] five hundred letters, and a third, one thousand letters, and so on, and thereby the plaintiffs' copyright be totally destroyed." (9 F.Cas. 342 (C.C.D. Mass. 1841) at 349).
} 
strongly endorsed the test, stating that "there is no circularity in saying, as we do say, that the potential for destruction of this market by widespread circumvention of the plaintiffs' permission fee system is enough, under the Harper \& Row test, 'to negate fair use."'), and Georgia State. ${ }^{71}$

There is yet no Canadian equivalent of the market harm test, and it is doubtful that Canadian courts would endorse it. In both Alberta and SOCAN the Court dismissed the argument that aggregate use would make the dealing unfair: 'Since fair dealing is a 'user's' right, the 'amount of the dealing' factor should be assessed based on the individual use, not the amount of dealing in the aggregate." 72 Although this statement is made in the context of the third factor (amount of the dealing) rather than the sixth (market effect), the same reasoning could be applied in response to an argument that widespread use might cause substantial market harm. If fair dealing is the right of the user, and not simply a privilege or benefit to the public in general, it should not matter how many individual users take advantage of it. A right does not become less of a right when many people reap its benefits.

A second significant difference between the Canadian and American approaches to the market effect factor is the relevance of a permission licensing scheme (although in a fair dealing analysis, this consideration falls under factor four, alternatives to the dealing). In short, the availability of a licence is relevant to a fair use analysis, but is not relevant to a fair dealing analysis.

The primary licensor for text reproduction in the U.S. is the Copyright Clearance Center. In Canada, COPIBEC and Access Copyright are rights administration collectives that offer licences

\footnotetext{
${ }^{71}$ Harper \& Row, supra note 62 at 568; Sony, supra note 49 at 451; Campbell, 510 U.S. 569, 114 S.Ct. 1164 (1994) at 590, online: Cornell LII <http://www.law.cornell.edu/supct/html/92-1292.ZS.html>; Basic Books, supra note 63 at 1534; Texaco, supra note 48 at 928; Princeton, supra note 46 at para. 28; Georgia State, supra note 37 at 1236. ${ }^{72}$ Alberta, supra note 1 at para. 29; SOCAN, supra note 1 at para. 41 .
} 
to users within Quebec, and in the rest of Canada, respectively. These licences may be transactional (one-time payment for a particular use of a work), or blanket/repertoire (yearly payment for ongoing limited use of a collection of works). Licences may also be offered directly by publishers. Licences represent an additional market for copyright owners: even if a book is out of print (and thus there is no sales market), licensing ensures that copyright owners can continue to earn money from reproduction of parts of the work. (Note that organizations such as the Copyright Clearance Center and Access Copyright do not provide the work itself - payment is merely for permission to use a work to which a user already has access.)

For the purposes of a fair use analysis, the U.S. courts have taken the availability of a reasonable licence as an indication that the use is less fair, particularly for "non-transformative" works. In Sony the Court said, had the studios developed a market whereby users of video cassette recorders could pay a licence to copy television programmes, that market would be taken into account. ${ }^{73}$ Likewise, in Texaco the Court said that, since the development of licensing schemes for photocopying journal articles, it is now appropriate to consider the publishers' loss of this revenue in evaluating the market effect factor, ${ }^{74}$ and perhaps even the purpose factor, to the extent that copying articles without permission may have been "reasonable and customary" before the existence of photocopy licensing arrangements. ${ }^{75}$ In the Georgia State decision, the Court agreed with Texaco that the existence of an easily accessible, convenient, and reasonably priced, should be considered in a fair use determination. ${ }^{76}$ It went so far as to suggest that " $[\mathrm{t}]$ he only practical way to deal with factor four in advance likely is to assume that it strongly favors

\footnotetext{
73 supra note 49 at 446 fn 28.

74 supra note 48 at 931.

75 ibid. at 924.

${ }^{76}$ supra note 37 at 1237.
} 
the plaintiff-publisher (if licensed digital excerpts are available). ${ }^{, 77}$ In other words, where a licence is available, the presumption is that the fourth factor would be decided in favour of the copyright owner, unless it can be shown that there would not be a substantial loss of licensing revenue.

In other cases, however, the mere existence of a licence does not automatically turn the fourth factor against the user. If the licence is unlikely to be granted (for example, in a parody situation such as Campbell), or if the cost would be astronomical (see HathiTrust), it would not be seen as less fair to use the work, because the copyright owner would not have earned revenue in the first place. $^{78}$

In Canada, the availability of licence, even at reasonable terms, is not considered at all. The Supreme Court in $\mathrm{CCH}$ said:

The availability of a licence is not relevant to deciding whether a dealing has been fair. As discussed, fair dealing is an integral part of the scheme of copyright law in Canada. Any act falling within the fair dealing exception will not infringe copyright. If a copyright owner were allowed to license people to use its work and then point to a person's decision not to obtain a licence as proof that his or her dealings were not fair, this would extend the scope of the owner's monopoly over the use of his or her work in a manner that would not be consistent with the Copyright Act's balance between owner's rights and user's interests. ${ }^{79}$

Justice Merritt expresses a similar concern in his dissent in Princeton: "It is also wrong to measure the amount of economic harm to the publishers by loss of a presumed license fee $-\mathrm{a}$ criterion that assumes that the publishers have the right to collect such fees in all cases where the user copies any portion of published works. ${ }^{\prime 80}$ While copyright owners certainly do have a right

\footnotetext{
77 ibid. at 1363.

${ }^{78}$ Note also that in each of these cases the use was considered to be transformative.

${ }^{79}$ supra note 2 at para. 70.

${ }^{80}$ supra note 63 at para. 85 .
} 
to collect licence fees for certain uses of their work, when there are free uses explicitly permitted in the legislation, there must be limits on what kinds of uses they may seek payment for.

Otherwise, the doctrines of fair dealing and fair use would be weakened based solely on the decision of copyright owners to offer licences for any and all extracts. If the doctrines arose primarily because it was too difficult to extract payment for all uses of the work, then a convenient licensing scheme would tend to negate its significance. However, fair dealing and fair use exist as a counterbalance to exclusive rights in order to encourage cultural and scholarly progress.

Copyright owners may, of course, offer licences for any possible use of the work, no matter the amount. The Copyright Clearance Center acknowledges that their fees are "net of fair use", meaning that they do not take the exception into account. ${ }^{81}$ This means that they will offer a licence for a use that could otherwise clearly be fair, or charge a per-page fee that does not subtract the portion that would be fair use. They will even calculate and accept payment for minuscule extracts. For example, the cost for permission to photocopy a single page (or 0.08 percent) of the textbook Sage Handbook of Qualitative Research (3rd ed.) for distribution to one student is US\$3.64 (not including sales tax).

Similarly, Access Copyright's web site includes a pricing schedule for transactional licences. The minimum charge is $\mathrm{CD} \$ 5.00$ plus applicable sales tax, so permission to copy a one page of a book in Access Copyright's repertoire, for use by one student, would cost CD $\$ 5.65$ in Ontario. ${ }^{82}$ (However, unlike the Copyright Clearance Center, Access Copyright does not offer transactional

\footnotetext{
${ }^{81}$ Georgia State, supra note 37 at 1215.

${ }^{82}$ Such a use may not even rise to the level of "substantiality" that would invoke the copyright owner's exclusive rights as per s. 3(1) of the Canadian Copyright Act (supra note 7), or rise above de minimis copying such that a fair use analysis would be necessary (Georgia State, supra note 37 at 1229).
} 
licences to post-secondary institutions that do not already have a blanket agreement with the collective. ${ }^{83}$ )

It is interesting to note, then, that a fair use analysis will consider potential market harm should unlicensed use become a widespread practice, but does not take into account the revenues earned from licences for uses that may clearly be fair and thus do not require payment at all. In a fair dealing analysis, on the other hand, neither "widespread use" nor licence availability are considered.

\section{$\underline{\text { II.6 - Institutional practice and internal policy }}$}

The market harm test in fair use looks at the possibility of a use becoming widespread, and whether this would lead to substantial harm to the market for the work or for permissions. On the flip side, the existing practices within a given sector (such as the post-secondary educational sector, or the commercial copy shop industry) may be taken into consideration.

The Supreme Court indicated in $\mathrm{CCH}$ that industry practice may be relevant in assessing the fairness of the character of the dealing. If a defendant's dealing was far beyond what is actually the norm in the industry, the dealing may be less fair. ${ }^{84}$ (Presumably, if the defendant's dealing comports with custom it would not weigh against her.)

In Basic Books and Princeton, the courts considered the "Agreement on Guidelines for Classroom Copying in Not-for-profit Educational Institutions with Respect to Books and Periodicals" ${ }^{\prime 55}$ (Classroom Guidelines) - a set of non-binding, general rules negotiated in 1976 by representatives of publishers and educators, meant to represent a sort of industry standard or safe

\footnotetext{
${ }^{83}$ Howard Knopf, “Access Copyright Responds to Motion and Submissions re Alleged Refusal to Provide Transactional Licenses" [blog post] (18 July 2011), online: < http://excesscopyright.blogspot.ca/2011/07/acresponds-re-alleged-refusal-to.html $>$.

${ }^{84}$ supra note 2 at para. 55; D’Agostino, supra note 21 at 320.

${ }^{85}$ The guidelines were published in HR Report No. 94-1476, supra note 16.
} 
harbour - as an additional factor outside of the statutory four. Both found that the copying in question was far outside the parameters of the agreement. (Just how much weight the Classroom Guidelines were given is not clear, since the four-factor assessment already pointed in favour of the copyright owners. ${ }^{86}$ ) In Georgia State, the Court criticized the Classroom Guidelines as being overly-restrictive for teaching purposes and did not take them into account. ${ }^{87}$

Industry practice may be determined in part by examining the policies followed by various institutions. The abovementioned Classroom Guidelines have been explicitly adopted by some American universities as policy, while other schools point to them as merely illustrative. The courts have considered the guidelines on several occasions (although not at the Supreme Court level) as a representation of industry norms, whether or not the defendant institution has appropriated them.

In the most recent case involving fair use in education, Georgia State, the defendants relied in part on their updated copyright policy and fair use checklist. ${ }^{88}$ The District Court did not consider these documents in its analysis of the four factors (or in any of the additional factors). Instead, the policy was addressed only insomuch as it was said to have caused infringements because it did not limit copying to "decidedly small excerpts" or provide guidance on determining likely market effect. ${ }^{89}$ The defendants also submitted evidence describing the copyright policies of other universities as compared to its own (in that other policies are more "liberal"), but the Court did not give any weight to the evidence because without explicit judicial

\footnotetext{
${ }^{86}$ Crews, supra note 40 at 661-663.

${ }^{87}$ supra note 37 at 1234 .

${ }^{88}$ These documents can be found at the University System of Georgia web site: http://www.usg.edu/copyright.

${ }^{89}$ supra, note 37 at 1363.
} 
guidance regarding the extent of fair use in non-profit educational settings, the schools (including Georgia State) were merely "guessing". 90

In a fair dealing analysis, the defendant's internal policies may be considered in lieu of showing that each individual dealing was fair, which was one of the bases of the Canadian Supreme Court's decision in $\mathrm{CCH}$ : "This raises a preliminary question: is it incumbent on the Law Society to adduce evidence that every patron uses the material provided for in a fair dealing manner, or can the Law Society rely on its general practice to establish fair dealing? I conclude that the latter suffices."91

Reasonable policies, therefore, carry more weight in favour of the user in fair dealing than they do in fair use.

\section{$\underline{\text { II.7 - Conclusion: burden of proof }}$}

The burden of proof in a claim of fair dealing or fair use is on the defendant, as it is an affirmative defence. ${ }^{92}$ However, this burden is lessened in fair dealing as compared to fair use, especially in educational and library contexts, if one considers the arguments in the preceding sections.

In Canada, the level of transformativity of the dealing is not given great significance. The defendant does not have to show that she has "added value" to the excerpt by incorporating it directly into a new work or using it for a new purpose. There is no requirement that the excerpt be smaller in proportion to the whole work in a non-transformative use as compared to a transformative use.

\footnotetext{
90 ibid. at 1232.

${ }^{91} \mathrm{CCH}$, supra note 2 at para. 63.

92 ibid. at para. 48; HathiTrust, supra note 55 at 458 (citing Texaco, supra note 48 at 918).
} 
Similarly, there is no presumption in fair dealing that the qualitative value of the excerpt is significant simply because the user has chosen to copy it. The defendant, therefore, need not worry about rebutting it.

There seems to be more support in fair dealing jurisprudence that the onus to demonstrate negative market effect, in a practical sense, lies with the plaintiff. In $\mathrm{CCH}$, while the Supreme Court acknowledged that the burden, procedurally speaking, is on the defendant, it also noted that the defendant did not have access to the plaintiff's financial information. The Court suggested that if there was evidence of such an effect, "it would have been in the publishers' interest to tender it at trial. ${ }^{.93}$ In Alberta, the Court interpreted this to mean that negative market effect due to the defendant's dealing with the works had not been demonstrated. ${ }^{94}$

So, it appears that where there is no evidence tendered by either side in regards to market effect, the sixth fair dealing factor may simply not be taken into account. ${ }^{95}$

In the U.S., it is not entirely clear whose burden it is to demonstrate negative market effect or lack thereof. In some U.S. cases, such as the 1973 William \& Wilkins Company v. United States (Williams \& Wilkins), the burden seemed to be on the plaintiff, ${ }^{96}$ while in Sony and Princeton, the Court said that if the intended use is for commercial gain, the likelihood of negative market effect would be a rebuttable presumption, and if the use is non-commercial, it would have to be proved by the plaintiff. ${ }^{97}$ In Texaco, it could be a burden of the plaintiff $o r$ the defendant;

\footnotetext{
${ }^{93} \mathrm{CCH}$, supra note 2 at para. 72

${ }^{94}$ Alberta, supra note 1 at para. 35; Geist, supra note 29 at 176.

${ }^{95}$ Vaver, supra note 36 at 243.

96487 F. 2d 1345 (C.C. 1973) at 1359, online: Stanford <http://fairuse.stanford.edu/case/c487f2d1345/>. Note, however, that this case was decided before the codification of the fair use provision.

${ }^{97}$ Sony, supra, note 49 at 451; Princeton, supra note 46 at para. 18.
} 
whoever has the evidence can sway the factor in their favour. ${ }^{98}$ In Georgia State, which had to do with a non-commercial, educational use, the burden was on the defendant to show insubstantial market effect, and if there is a licence available, a substantial market effect is assumed. ${ }^{99}$

Even if the burden were strictly on the plaintiff, he may discharge it via the so-called market harm test, by showing on a preponderance of the evidence that widespread use of the sort at issue would lead to significant loss of revenues or likely revenues. There is no such test in a Canadian fair dealing analysis. ${ }^{100}$

The availability of a licence, although not dispositive of fair use, tends to orient the fourth factor towards unfairness. The defendant may be able to negate this presumption by demonstrating that the cost of the licence is unreasonable, that the licensing process is unduly complicated or inconvenient, or that the plaintiff has already refused permission. ${ }^{101}$ Such an effort is unnecessary for a defendant claiming fair dealing, since licences are not a relevant consideration in a fair dealing analysis.

Perhaps the most significant development in the law of fair dealing from the point of view of educational institutions and libraries is the Court's expansion of the role of internal policies. The Supreme Court has said that an institution does not have to show that each and every dealing made under its roof is fair; it suffices that the usual practice (which can be adduced by reference to an internal policy) can be considered instead. This means that if a university or library

\footnotetext{
98 supra, note 48 at 928.

99 supra, note 37 at 73,75 .

${ }^{100}$ see Section II.5, supra.

${ }^{101}$ Basic Books, supra note 63 at 1535: “[D]efendant's witnesses did not produce evidence which would explain why they could not seek and pay for permission to create these anthologies."
} 
develops and makes available a reasonable and appropriate copyright policy, it is not necessary to gather evidence demonstrating that all copies are fair. ${ }^{102}$

The differences in burden between fair dealing and fair use are not arbitrary; they reflect a fundamental variance in the overall conception of the purpose of the provisions. As the Court in $\mathrm{CCH}$ put it: "Procedurally, a defendant is required to prove that his or her dealing with a work has been fair; however, the fair dealing exception is perhaps more properly understood as an integral part of the Copyright Act than simply a defence." ${ }^{103}$ Lessening the burden on the user ensures that fair dealing is given a broad and liberal interpretation, maintaining the balance that copyright represents. ${ }^{104}$ If copyright is thought of not as a balance of rights but as an instrument for the progress of arts and sciences, then insofar as a restrictive view of exceptions to exclusive rights is necessary to achieve this objective, a defendant's burden of establishing fair use is correspondingly expanded.

\section{PART III - Advocacy and best practices among administrators and associations}

Fair dealing and fair use are complex doctrines, and the vast majority of users are not familiar with their existence, let alone their intricacies. ${ }^{105}$ Fair dealing, fair use, and other exceptions cover a wealth of uses in the educational sector, but there remains among many administrators (moreso in Canada than in the U.S.) a sense that they need to be overly cautious lest they face a lawsuit for copyright infringement. This attitude of risk aversion leads them to sign blanket

\footnotetext{
102 D'Agostino, supra note 21 at 325.

103 supra note 2 at para. 48.

${ }^{104}$ Scassa, supra note 17 at 94. "[B]y framing the defence narrowly, it invites a more restrictive approach to interpretation." See also Ned Snow, "Proving Fair use: Burden of Proof as Burden of Speech" (2010) 31:5 Cardozo Law Review 1781 at 1812. "The burden affects judicial conception of fair use, and that conception affects the substantive outcome of decisions" in that uncertainty or ambiguity tends to favour the plaintiff.

105 Tony Horava, "Webpages on Copyright in Canadian Academic Libraries" (2008) 3:2 Partnership: The Canadian Journal of Library and Information Practice and Research at 1-2, online: Partnership <http://journal.lib.uoguelph.ca/index.php/perj/article/view/583 > .
} 
licensing agreements that contain strict terms and vague reporting provisions and that provide little additional benefit to users. ${ }^{106}$ Instead of promoting awareness of fair dealing and its integral role in copyright, this approach implies that it is to be relied upon only sparingly, and that it is better to be "safe" by getting permission than "sorry" by risking legal action. As discussed in Section II.6, supra, institutional practice may have an influence on the interpretation of fair dealing by the courts, so broad and consistent fair dealing policies and practice in post-secondary education and libraries could prevent weakening of user rights. ${ }^{107}$

Fair dealing and fair use advocacy by professional library and education associations will help to ensure that the interests of these groups are represented in government policy. Furthermore, development by associations of best practices in copyright will provide guidance to administrators, instructors, and librarians in understanding and taking advantage of fair dealing or fair use.

\section{$\underline{\text { III. } 1 \text { - Advocacy }}$}

\section{United States}

Associations of educators and librarians in the U.S. are known for their activism on issues, including copyright, that affect the ability of universities and libraries to fulfill their objective of providing access to information.

Since 2007, the American Library Association (ALA) has maintained a Copyright Discussion Group "designed to respond quickly [to] hot topics" and allow for the exchange of ideas among

\footnotetext{
${ }^{106}$ Samuel Trosow, Brent Harasym \& Scott Armstrong, "Objections to the Proposed Access Copyright PostSecondary Tariff and its Progeny Licenses: A Working Paper" (2012), online: Scholarship@Western $\langle$ http://ir.lib.uwo.ca/fimspub/24/>.

${ }^{107}$ Trosow, supra note 4; James Gibson, "Risk Aversion and Rights Accretion in Intellectual Property Law" (2007) 116 The Yale Law Journal 882, online: SSRN < http://ssrn.com/abstract=918871> (discussing "doctrinal feedback" in U.S. intellectual property law).
} 
members about copyright issues that affect academic and research libraries. ${ }^{108}$ The director of the Program on Public Access to Information is responsible not only for advocacy but also for the development of educational programs and public resources related to copyright, and for responding to government requests for input. ${ }^{109}$ The association's “Advocacy, Legislation \& Issues" web page contains a discussion of fair use, ${ }^{110}$ including a link to a fair use evaluator to help users understand and apply the four factors, ${ }^{111}$ and free webinars.

The ALA, along with the Association of Research Libraries (ARL) and the Association of College and Research Libraries (ACRL), is a member of the Library Copyright Alliance (LCA), an organization that advocates on issues of copyright, including fair use; its mission is to "foster global access and fair use of information for creativity, research, and education." $" 112$

The Association of American Universities maintains a web page on the subject of fair use, mainly relating to technological protection measures. ${ }^{113}$ The American Association of University Professors (AAUP) likewise discusses fair use in various parts of its web page, particularly with regards to its impact on faculty. ${ }^{114}$

These organizations are also active in the courts, filing or signing on to amicus curiae briefs in fair use cases such as Williams \& Wilkins (ALA, ARL, Medical Libraries Association, and

\footnotetext{
${ }^{108}$ American Library Association, "Copyright Discussion Group” (n.d.), online: ALA <http://www.ala.org/acrl/aboutacrl/directoryofleadership/discussiongroups/acr-dgcopy >.

109 American Library Association, "Program on Public Access to Information" (n.d.), online: ALA <http://www.ala.org/offices/oitp/programs/publicaccesstoinfo >.

${ }^{110}$ American Library Association, "Fair Use" (n.d.), online: ALA < http://www.ala.org/advocacy/copyright/fairuse $>$.

${ }^{111}$ American Library Association, "Fair Use Evaluator" (n.d.), online: Copyright Advistory Network $<$ http://librarycopyright.net/resources/fairuse/>.

${ }^{112}$ Library Copyright Alliance, "Background" (2009), online: LCA <http://www.librarycopyrightalliance.org/about/index.shtml $>$.

${ }^{113}$ Association of American Universites, "Fair Use" (n.d.), online: AAU <http://www.aau.edu/policy/fair_use.aspx?id=9524>.

${ }^{114}$ American Association of University Professors, "Intellectual Property Issues for Faculty" (2006), online: AAUP <http://www.aaup.org/issues/copyright-distance-education-intellectual-property/resources-copyright-distanceeducation-and/intellectual-property-issues-faculty>.
} 
American Association of Law Libraries in the Circuit Court; ALA, ARL, and the Special Libraries Association in the Supreme Court), Texaco (ALA and ARL), Princeton (ARL), HathiTrust (LCA), and the Georgia State appeal (ALA, ARL, ACRL, AAUP, and a group of academics and legal scholars).

\section{Canada}

Among educational administrators in Canada there is still very much a culture of risk aversion; despite the ruling in $\mathrm{CCH}$ that fair dealing is a user's right that is not to be interpreted restrictively, universities continue to enter into blanket licensing agreements that fail to offer much more than what may be permissible under fair dealing and other exceptions. ${ }^{115}$ In 2012 , well after $\mathrm{CCH}$ but before the Copyright Pentalogy was decided, 54 percent of universities outside Quebec with student populations of 5,000 or more had signed new agreements with Access Copyright. ${ }^{116}$ The remainder opted instead to rely on the legislated exceptions, along with publishers' licenses, open access materials, and public domain works. (By contrast, American universities tend to avoid blanket licences in favour of alternatives, using transactional licences when required. ${ }^{117}$ )

The Association of Universities and Colleges of Canada (AUCC), the board of which is made up of university presidents, has also been taking an overly-cautious stance towards fair dealing as of late. The AUCC (along with the Association of Community Colleges of Canada) had originally filed with the Copyright Board an objection, on behalf of its member universities, to Access Copyright's proposed tariff in 2010. However, in April 2012 the AUCC reached an agreement

\footnotetext{
115 Trosow, supra note 4.

${ }^{116}$ Lisa Di Valentino, "Review of Canadian University Fair Dealing Policies” (2013), online: SSRN <http://ssrn.com/abstract=2263034>.

${ }^{117}$ Ariel Katz, "The GSU Copyright Case: Some Canadian Perspectives" [blog post] (14 May 2012), online <http://arielkatz.org/archives/1771>.
} 
with Access Copyright on a model blanket licence, and subsequently withdrew its objection to the tariff. ${ }^{118}$ Additionally, it has not sought judicial review of the interim tariff set out by the Copyright Board in April 2011.

Access Copyright filed a new tariff application for reprographic reproduction of literary works by post-secondary educational institutions in May 2013. ${ }^{119}$ The AUCC did not file an objection to this tariff application. ${ }^{120}$ The organization has engaged in some advocacy, as it appeared as an intervener in the Alberta case, where it was permitted to make an oral argument. ${ }^{121}$

Interestingly, the AUCC has not made any public statement regarding Access Copyright's lawsuit against York University, despite that York's fair dealing policy is based on the AUCC's revised guidelines.

The Association of Community Colleges of Canada (ACCC) is the AUCC's sibling organization for community colleges and polytechnics. Although the associations are made of up of different types of institutions, they often collaborate in advocacy activities. The ACCC joined the AUCC in its objection to the proposed tariff in 2010, but unlike the latter, it did not withdraw its objection. The ACCC has also filed an objection relating to the new tariff in $2013 .{ }^{122}$

\footnotetext{
${ }^{118}$ Glen A. Bloom, Letter to Copyright Board (24 April 2012), online: Scribd $<$ http://www.scribd.com/doc/91075676/AUCC-Withdrawal-Letter-April-24-2012〉.

${ }^{119}$ Access Copyright Post-Secondary Educational Institution Tariff, 2014-2017 (18 May 2013) Supplement to the Canada Gazette, Part I, online: Copyright Board <http://www.cb-cda.gc.ca/tariffs-tarifs/proposedproposes/2013/Supplement_18_may_2013.pdf>.

${ }^{120}$ Howard Knopf, "Deadline Passes for Objections to Access Copyright (Post-Secondary Educational Institutions Tariff) 2014-2017" [blog post] (19 July 2013), online: <http://excesscopyright.blogspot.ca/2013/07/deadline-passesfor-objections-to.html>.

${ }^{121}$ Alberta, supra note 1 (Factum of the Intervenors Association of Universities and Colleges of Canada and Association of Community Colleges of Canada), online: Scribd < http://www.scribd.com/doc/73790696/AUCC-andACCC-Factum-Search-Able>.

${ }^{122}$ Knopf, supra note 120.
} 
Like the AUCC, the ACCC had negotiated a model licence with Access Copyright that was subsequently entered into by several institutions. However, its own legal counsel has advised it that there is "little value" to signing the agreement. ${ }^{123}$

While the AUCC and ACCC are made up of administrators, the Canadian Association of University Teachers (CAUT) is a federation of faculty associations and faculty unions. Along with the Canadian Federation of Students, the association filed objections to both of Access Copyright's tariff applications (2010 and 2013), and made a submission as interveners in Alberta.

The Canadian Library Association (CLA), advised by its Copyright Advisory Committee, advocates on copyright issues that impact libraries and their patrons, and provides a "grassroots advocacy kit" for individuals and organizations. ${ }^{124}$ The CLA has also made public statements in relation to Bill C-11 125 and filed an objection to the 2010 tariff application (though not the 2013 tariff application). ${ }^{126}$ It has released a statement criticising Access Copyright's suit against York University, ${ }^{127}$ but also characterized the negotiation of a model licence as a "welcome

\footnotetext{
${ }^{123}$ Canadian Association of University Teachers, "Access Copyright Isolated” 59 CAUT Bulletin 7 (September 2012), online: CAUT < http://www.cautbulletin.ca/en_article.asp?articleid=3520>; Michael Geist, "ACCC Legal Counsel: Access Copyright Licence Provides 'Little Value"” [blog post] (September 6, 2012), online: <http://www.michaelgeist.ca/content/view/6627/125/>.

${ }^{124}$ Canadian Library Association, "Fair and Balanced Copyright for Canadians". (n.d.), online: CLA <http://www.cla.ca/AM/Template.cfm?Section=Copyright_Information\&Template=CM/ContentDisplay.cfm\&Cont entID=4507>.

${ }^{125}$ Canadian Library Association, "Protecting the Public Interest in the Digital World: Revisited for Bill C-11" (12 December 2011), online: CLA <http://www.cla.ca/Content/NavigationMenu/Resources/Copyright/Protecting the Public Interest in the Digital World_FINALdec11.pdf $>$.

${ }^{126}$ Canadian Library Association, "Canadian Library Association Objection to the Access Copyright Post Secondary Educational Institutions Tariff for 2011 - 2013" (27 July 2010), online: CLA <http://www.cla.ca/Content/ContentFolders/NewsReleases/2010/CLA_Tariff_objections_jul2010_final.pdf >.

${ }^{127}$ Canadian Library Association, "CLA Statement on Access Copyright lawsuit against York University” (17 May 2013), online: CLA <http://www.cla.ca/Content/NavigationMenu/Resources/Copyright/CLA_Statement_on_Access_CopyrightYork may13.pdf>.
} 
development" (in relation to the alternative of facing a tariff proceeding). ${ }^{128}$ Furthermore, unlike its American counterpart the ALA, the CLA has not yet been involved as an intervener in fair dealing court cases.

The Canadian Association of Research Libraries (CARL), whose board is made of library directors, advocates for fair copyright legislation. ${ }^{129}$ CARL has spoken at the House of Commons during the Bill C-32 consideration process, ${ }^{130}$ and made statements against Access Copyright's suit against York University, ${ }^{131}$ but has failed to participate in some litigation as intervenors and has not made any statements in regards to the model licence negotiated by the AUCC.

\section{$\underline{\text { III. } 2 \text { - Best practices }}$}

Best practices and policies are important tools for managing copyright compliance within institutions, and for avoiding liability. In Canada, a reasonable official institutional policy may be considered in a judicial fairness analysis in lieu of individual dealings with works (see Section II.6, supra). A policy may be more persuasive if it is based on best practices established across the industry or sector. ${ }^{132}$

\footnotetext{
${ }^{128}$ Canadian Library Association, "CLA Statement on Licenses with Access Copyright in Post-Secondary Institutions" (26 June 2012), online: CLA <http://www.cla.ca/Content/NavigationMenu/Resources/Copyright/CLA_Statement_Postsecondary licenses with_Access_Copyright_june12 final.pdf>.

${ }^{129}$ Canadian Association of Research Libraries, "Copyright" (n.d.), online: CARL $<$ http://www.carlabrc.ca/copyright.html>.

${ }^{130}$ Legislative Committee on Bill C-32, Evidence, 40th Parl., 3rd Sess. (February 15, 2011), online: Parliament of Canada

$<$ http://www.parl.gc.ca/HousePublications/Publication.aspx?DocId=4967582\&Language=E\&Mode=1\&Parl=40\&Se s=3\#Int-3747141>.

${ }^{131}$ Canadian Association of Research Libraries, "CARL Condemns Access Copyright's Lawsuit against York University" (April 11, 2013), online: CARL < http://www.carl-abrc.ca/news/69/201/CARL-Condemns-AccessCopyright-s-Lawsuit-against-York-University.html>.

${ }^{132}$ D'Agostino, supra note 21 at 362.
} 


\section{United States}

In the U.S. there are several model policies and codes of best practices for fair use that have been developed by various organizations. While the fair use provision was being debated in the House of Representatives in the mid-1970s, representatives of publishers and educational administrators negotiated what would become the Classroom Guidelines. Guidelines also emerged from other negotiations, such as the Proposal for Educational Fair Use Guidelines for Distance Learning, and the Proposal for Fair Use Guidelines for Educational Multimedia. ${ }^{133}$

Meanwhile, American library and educational societies have put together model policies and codes of best practices for specific types of institutions or particular subject matters. ${ }^{134}$ In 1982 the ALA developed a model policy for copying by colleges and universities. ${ }^{135}$ More recently, the ARL, the Center for Social Media, and the Washington College of Law have jointly coordinated a code for academic and research libraries. ${ }^{136}$ The Society for Cinema and Media Studies has developed a code for film and media instructors, ${ }^{137}$ and the International Communication Association has authored a Code of Best Practices in Fair Use for Scholarly Research in Communication. $^{138}$

\footnotetext{
133 see Crews, supra note 40.

${ }^{134}$ For a discussion of best practices and examples, see Aufderheide \& Jaszi, supra note ___ at 108ff and the accompanying web site of the Center for Social Media, "Fair Use Codes \& Best Practices" (n. d.), online: Center for Social Media <http://www.centerforsocialmedia.org/fair-use/best-practices/fair-use-codes-best-practices > .

${ }^{135}$ American Library Association, "Model Policy Concerning College and University Photocopying for Classroom, Research and Library Reserve Use" (1982), online: Coalition for Networked Information <http://old.cni.org/docs/infopols/ALA.html>.

${ }^{136}$ Association of Research Libraries, "Code of Best Practices in Fair Use for Academic and Research Libraries" (January 2012), online: ARL <http://www.arl.org/focus-areas/copyright-ip/fair-use/code-of-best-practices>.

${ }^{137}$ Society for Cinema and Media Studies, "The Society for Cinema and Media Studies' Statement of Best Practices for Fair Use in Teaching for Film and Media Educators" (2008), online:

<http://c.ymcdn.com/sites/www.cmstudies.org/resource/resmgr/fair_use_documents/scms_teaching_statement.pdf $>$. ${ }^{138}$ International Communication Association, "Code of Best Practices in Fair Use for Scholarly Research in Communication" (June 2010), online: Center for Social Media <http://centerforsocialmedia.org/fair-use/bestpractices/code-best-practices-fair-use-scholarly-research-communication $>$.
} 


\section{Canada}

In December 2010, Michael Geist wrote a blog post in which he suggested that best practices will "quickly emerge" if fair dealing were to be expanded to include education as an enumerated purpose. ${ }^{139}$ Since then, both the AUCC and the CAUT have developed guidelines or model policies.

The AUCC guidelines were created in $2012 ;{ }^{140}$ they represent a significant revision of the previous copying guidelines of $2011 .^{141}$ The policy adds "education, parody and satire" as permissible fair dealing purposes (following the enactment of Bill C-11), and allows for the creation of print or digital course packs. However, there is less background and context provided in the revised policy. While the content of the guidelines can be found via a site search or Google search, there is no incoming link from the AUCC's web page itself.

The CAUT fair dealing guidelines, created in 2013, are incorporated into a longer document about copyright in general. ${ }^{142}$ Unlike the AUCC policy, the CAUT guidelines provide more contextual information (such as the six fair dealing guidelines) and do not specify any particular limit or percentage that might be permissible.

Several universities have adopted or adapted the AUCC fair dealing policy, including York University. Fewer have taken on the CAUT guidelines as an institutional policy, but some university copyright web sites refer to it.

\footnotetext{
${ }^{139}$ Michael Geist, “Clearing Up the Copyright Confusion: Fair Dealing and Bill C-32” [blog post] (15 December 2010, online: <http://www.michaelgeist.ca/content/view/5519/125/>.

${ }^{140}$ Association of Universities and Colleges of Canada, "Fair Dealing Policy for Universities" (2012), online: AUCC <http://www.aucc.ca/fair-dealing-policy-for-universities/>.

${ }^{141}$ Association of Universities and Colleges of Canada, "Fair Dealing: Copying Guidelines" (2011), online: UBC <http://collections.library.ubc.ca/files/2011/03/AUCC-Fair-dealing-policy-March-2011.pdf>.

${ }^{142}$ Canadian Association of University Teachers, "CAUT Guidelines for the Use of Copyrighted Material” (2013), online: CAUT <http://www.caut.ca/docs/default-source/copyright/revised-caut-guidelines-for-the-use-ofcopyrighted-material-(feb-2013).pdf?sfvrsn=4>.
} 
In August 2013 the AUCC, in association with a leading Canadian law firm, developed another set of guidelines to replace the policy of 2012. ${ }^{143}$ These new documents are to provide guidance to specific user groups (for example, instructors) and for particular types of uses (such as course packs and learning management systems). The guidelines have not yet been made widely available, so it remains to be seen whether they further converge or diverge with those of the CAUT. $^{144}$

\section{III.3 - Why the divergence?}

In terms of fair use advocacy and activism, the American Library Association is more aggressive than its Canadian counterpart. The ALA has filed amicus briefs in several major court cases involving fair use in research or teaching, while the CLA has yet to intervene in fair dealing litigation. The American Association of Universities also seems to promote fair use more strongly than the Association of Universities and Colleges of Canada encourages reliance on fair dealing. Universities in Canada are much more likely to sign a blanket licensing agreement than are their American equivalents. If, as I have argued, educational fair dealing for the purposes of research or education is easier to demonstrate than fair use, in that the burden on defendants is reduced, why does there seem to be less of an impetus in taking advantage of these users' rights?

One explanation is that the current conception and interpretation of the wider scope of fair use in the educational context has simply been around longer. The Circuit Court in Williams \& Wilkins

\footnotetext{
${ }^{143}$ See Michael Geist, "Schools navigate learning curve for new copyright rules: Geist" (30 August 2013) The Star, online: The Star <http://www.thestar.com/business/2013/08/30/schools_navigate_learning_curve_for_new_copyright_rules_geist.ht $\mathrm{ml}>$.

${ }^{144}$ For a more detailed comparison of the AUCC and CAUT guidelines, see Di Valentino, supra note 116 at 19, 42 43.
} 
decision (which predates the codification of fair use), asserted that "in general, the law gives copying for scientific [research] purposes a wide scope."

When Section 107 was added to the American Copyright Act in 1976, "education" (including multiple copies for classroom use) was explicitly noted in the provision as one of the purposes envisioned by Congress. The four fair use factors were added to the legislation to provide guidance to courts as well as users. At the same time, representatives of publishers and educational institutions created the Classroom Guidelines, which were favourably commented upon by the House Judiciary Committee as being a "reasonable interpretation of the minimum standards of fair use."146 The ALA followed a few years later with a model policy addressing fair use rights in the academic and library sectors.

In Canada, on the other hand, although fair dealing has been a part of the Copyright Act since 1921, the factors to be taken into consideration in a fair dealing analysis were not set out in Canadian jurisprudence until 2002, and education was not an enumerated purpose until 2012. It was not until 1997 that a fair dealing suit in any court was decided in favour of the defendant, and it was 2004 before the Supreme Court adjudged a dealing to be fair. Even though the Court in $\mathrm{CCH}$ described fair dealing as a "users' right" to be interpreted broadly, the case related to the already-enumerated purpose of research, and not education per se. Only in 2012, when Alberta was decided, and the Copyright Act was amended, was it undeniable that copying excerpts for use as classroom handouts could be considered fair. ${ }^{147}$

\footnotetext{
${ }^{145}$ Williams \& Wilkins, supra note 96 at 1354.

${ }^{146}$ U.S., House Judiciary Committee, supra note 16 at 72.

${ }^{147}$ Ariel Katz argues that fair dealing was meant to be interpreted broadly since it was first codified in Canada, but misconceptions of the doctrine in early cases resulted in a more restrictive approach that was not remedied until $\mathrm{CCH}$; see "The Rebirth of Fair Dealing in Canada" in Michael Geist, ed., The Copyright Pentalogy: How the
} 
Meanwhile, university administrators, on the advice of legal counsel, signed blanket licence agreements with Access Copyright, in part because the alternative was thought to be too risky. In 2012, anticipating the legislative amendments and Supreme Court decisions in favour of fair dealing, some universities opted to "go it alone", but the majority entered into subsequent agreements with the collective. The AUCC, being made up of administrators, encouraged this outcome by negotiating a model licence for its members and dropping its objection to the proposed tariff. Michael Geist supposes that the AUCC was not prepared to deal with fair dealing issues because permissions were always taken care of by licences in the past:

AUCC has never appeared comfortable with the copyright file. For years, its members paid millions to Access Copyright without giving it much thought. It was only after the collective sought a massive increase that it captured the attention of senior officials at Canadian universities, who began to question the value of the licence. ${ }^{148}$

In other words, it was business as usual until Access Copyright asked for more money.

In the same vein, because universities were accustomed to these licences and the convenience and indemnity that they supposedly provided (not to mention that the fees were paid by students directly), "very few [of them] developed any internal expertise on copyright or any internal mechanisms that would allow them to feel confident about operating without access copyright." 149

As noted above, Canadian associations have been less likely than American associations to involve themselves in third-party litigation as intervenors. One may argue that Canadian courts in general are less amenable to intervenors and amici curiae than are U.S. courts, and so

Supreme Court of Canada Shook the Foundations of Canadian Copyright Law (Ottawa: University of Ottawa Press, 2013) 93, online: University of Ottawa Press <http://www.press.uottaLa.ca/the-copyright-pentalogy>.

${ }^{148}$ Michael Geist, “Access Copyright and AUCC Strike a Deal: What It Means for Innovation in Education” [blog post] (17 April 2012), online: <http://www.michaelgeist.ca/content/view/6423/125/>.

${ }^{149}$ Katz, supra note 17. 
organizations are less likely to spend time and money on factums and filings if there is a slim chance of being permitted to intervene. However, while this may or may not have been true in the past, the proportion of applicants who are permitted to intervene at the Canadian Supreme Court has grown over the last 30 years. ${ }^{150}$ Between 2000 and 2008, trade associations who applied for leave to intervene were granted leave 95 percent of the time, while public interest groups were granted leave 87 percent of the time. ${ }^{151}$

There were, in fact, quite a few intervenors in the Copyright Pentalogy cases. In Alberta the Supreme Court granted leave to, among others, the CAUT and CFS, the AUCC, the ACCC, the Samuelson-Glushko Canadian Internet Policy and Public Interest Clinic (CIPPIC), and the Centre for Innovation Law and Policy of the University of Toronto. Intervenors in the SOCAN case included the CAUT, CIPPIC, the Canadian Legal Information Institute, and the Federation of Law Societies of Canada.

\section{$\underline{\text { III.4 - Going forward }}$}

"One person's uncertainty is another person's flexibility." ${ }^{\prime 152}$ Fair dealing and fair use provisions were drafted with flexibility in mind. While copyright may be a "creature of statute", its interpretation is also guided by the courts. Canadian courts have provided some guidance in the form of the six fair dealing factors; analysis is to be done on a case-by-case basis, and fair dealing must not be interpreted restrictively. There is, understandably, a preference by administrators for more (perceived) certainty and less (perceived) risk, and so they turn to

\footnotetext{
${ }^{150}$ Benjamin Alarie \& Andrew James Green, "Interventions at the Supreme Court of Canada: Accuracy, Affiliation, and Acceptance" (2010) 48:3 Osgoode Hall Law Journal 381, online: SSRN < http://ssrn.com/abstract=1498747>.

${ }^{151}$ ibid. at 398. While this article does not break down the percentages by area of law, the authors note that cases involving areas of law other than Charter, criminal, and aboriginal had intervention rates "fairly consistent with the average overall level."

${ }^{152}$ Sam Trosow (Lecture delivered at the PLG Copyright Roundtable, The University of Western Ontario, July 31, 2013) [unpublished].
} 
blanket licencing agreements that provide little additional value. This course of action essentially disregards fair dealing or gives the impression that it is a last resort rather than a user's right.

Instead, university and library administrators must take fair dealing seriously and realize that it is not a mere concession of copyright owners. Its scope includes most of the copying that goes on in these institutions. Schools should have a clear, but not overly-restrictive fair dealing policy accompanied by sufficient background information about copyright to make it understandable. ${ }^{153}$ These policies must be up-to-date and include a discussion of the fair dealing factors to provide guidance to users and allow them to make informed and confident decisions about whether their proposed use would be permissible. ${ }^{154}$ D'Agostino argues that we need to convince people of a bottom-up approach, where best practices are developed by stakeholders (including authors) and those who have direct experience with various practices and outcomes. ${ }^{155}$

Universities and colleges should institute a copyright office, centralized in the library, responsible for advising administrators on policy questions, assisting individual users, running workshops, and maintaining copyright information on the school's web page. This office would ideally be made up of a copyright expert and representatives from the library, faculty, and student body.

\footnotetext{
${ }^{153}$ Di Valentino, supra note 116 at 32; Samuel Trosow, "Fair Dealing Practices in the Post-Secondary Education Sector After the Pentalogy" in Michael Geist, ed., The Copyright Pentalogy: How the Supreme Court of Canada Shook the Foundations of Copyright Law (Ottawa: University of Ottawa Press, 2013) 213 at 215, online: University of Ottawa Press <http://www.press.uottawa.ca/the-copyright-pentalogy>.

${ }^{154}$ Crews, supra note 40 at 692.

${ }^{155}$ D'Agostino, supra note 21 at 355; D'Agostino, supra note 41 at 204.
} 
Finally, professional associations must continue to advocate aggressively for the rights of users. Advocacy includes intervening in litigation, making submissions to government, and developing model policies and best practices. ${ }^{156}$

Fair dealing will continue to evolve along with technologies and practices, and administrators and associations must realize that they are a strong influence on the direction of this evolution.

\section{Part V - Conclusion}

Copyright is not, and never has been, about giving complete control over the use of works to the author or copyright owner. It has always been a balance of some kind, whether between owners' rights and the public interest, or between owners' rights and users' rights. Creative output is all to some degree derivative of what has come before. ${ }^{157}$ The author is also a user, and the user may take parts of an author's work in order to create a new work, either directly or indirectly. Canadian courts recognize that the user is an integral part of the dialogue, and therefore an integral part of copyright. Fair dealing and other exceptions are given a broad scope. In practical terms, this means that the burden of proof on the defendant is significantly reduced, particularly in the non-profit academic and library sector, as compared to American fair use: the defendant does not have to show that she has transformed the original work; she does not have to rebut a presumption of qualitative value in the chosen excerpt; she does not have to argue that dealing of the sort at issue will not cause significant reduction in the plaintiff's revenues; the availability of a licence does not weigh against her; and she may rely on an institutional policy as proof that the dealings are fair.

\footnotetext{
${ }^{156}$ Kenneth Crews, Copyright, Fair Use, and the Challenge for Universities: Promoting the Progress of Higher Education (Chicago: The University of Chicago Press, 1993) at 133.

${ }^{157}$ Leval, supra note 42 at 1109; Drassinower, supra note 19.
} 
Nonetheless, educational administrators in Canada are more likely than those in the U.S. to sign blanket licences under the impression of reduced liability. Professional associations are less likely than in the U.S. to involve themselves in fair dealing litigation as intervenors or amici curiae. Such risk-aversion and restraint may be due to custom and lack of preparedness. From this point they must take control of fair dealing with reasonable and appropriate policies, and promote the user-centric approach that has been accorded by the legislators and courts. 